\title{
ARI POLENI PROTEINLERI VE FONKSIYONEL ÖZELLIKLERI
}

\author{
Bee Pollen Proteins and Their Functional Properties
}

\author{
Zeynep BAKKALOĞLU
}

İstanbul Rumeli Üniversitesi, Sanat ve Tasarım Fakültesi, Gastronomi ve Mutfak Sanatları Bölümü, İstanbul, TÜRKIYE, ORCID No: 0000-0002-8250-8478, E-posta: zeynep.bakkaloglu@rumeli.edu.tr

\section{ÖZ}

Bal ve arı ürünlerinden biri olan polen arılar için önemli besin kaynaklarındandır. Polen özellikle ergin, yaşlı ve larva dönemindeki arıların beslenmesinde protein, vitamin ve mineral madde gibi ihtiyaçlarının karşılanması için kullanılmaktadır. Polen içerisindeki protein oranı ile arıların beslenmesinde temel protein ihtiyacını karşıladığı için kovana yeterli düzeyde alınmalı ve uygun şartlarda depolanmalıdır. Arı poleni insan sağlığı için besleyici ve terapötik özelliklere sahiptir. Apiterapide, ilaç sanayinde, gıda endüstrisinde, arı yetiştiriciliğinde, hayvan yemi olarak, kozmetik sanayinde ve polinasyon çalışmaları gibi geniş bir kullanıma sahip arı poleninin fonksiyonel etkileri henüz tam olarak bilinememektedir. Arı poleninin teknik açıdan fonksiyonel gıda maddesi olarak olası kullanımı, fiziksel, kimyasal ve teknofonksiyonel özelliklerinin bilinmesine bağlıdır. Ancak arı polenlerinin çeşitli alanlarda kullanımında bu etkileri gözardı edilmektedir. Bunun nedeni arı polenlerinin toplandığı mevsim ve bölgeye bağlı olarak protein içeriğinin değişmesi ve bu değişimin polen proteinlerinin fonksiyonel özellikleri üzerine etkilerinin net şekilde ortaya konmamasıdır. Bu derleme ile literatür bilgileri ışığında, arı poleni proteinleri ve sahip oldukları fonksiyonel özelliklere temel oluşturulmuş ve daha fazla araştırma yapılmasına dikkat çekilmesi hedeflenmiştir.

Anahtar Kelimeler: Polen, Polen proteini, Fonksiyonel özellikler

\begin{abstract}
Consumption of bee products has increased significantly due to the their therapeutic and antiviral activity. Moreover it could offer nutrition improvement and reducing the risk of developing serious infectious diseases. Pollen is a bee product which used especially in the nutrition of adult, old and larval honeybees to meet their needs such as protein, vitamins and minerals. Depending on the botanical and geographical origins, bee pollen can be included different composition. Additionally, the protein content and composition of bee pollen are the major protein source of honeybees pollen. Although, the functional properties of bee pollen which have generally used in apitherapy, pharmaceutical industry, food industry, beekeeping, animal feed, cosmetic industry and pollination studies, the functional properties of bee pollen proteins have not been clearly revealed yet. Moreover, the using of bee pollen proteins as a functional food, it depends on physical, chemical, nutritional and technofunctional properties of its. In the literature, bee pollen proteins and their tecnofunctional using has not determined with all details yet. Therefore, in this review provides to determine the functional properties of bee pollen proteins and an overview opportunities for their use in various applications.
\end{abstract}

Keywords: Pollen, Pollen proteins, functional properties 


\section{EXTENDED ABSTRACT}

Goal: Bee proteins, one of the beekeeping products, have been consumed by people for years due to their antifungal, antimicrobial, antioxidant, antiinflammatory, antitumor, chemopreventive/ chemoprotective, and antiradiation benefits. Bee pollen, which can be consumed as human food, is very rich in protein. However, this protein content of the bee product has not been clearly investigated. In this study, first of all, bee pollen will be evaluated in terms of its physical, chemical and technofunctional properties such as protein solubility, emulsification properties, water and oil absorbtion capacity, foaming capacity and stability. Thus, the use of bee pollen proteins is not only for human health, but also in industry. The study also drew attention to further research for the functional properties of bee pollen proteins in order to contribute to the development of new functional products.

Discussion: For the technofunctional properties of bee pollen, the chemical ingredients of its such as carbohydrates, lipids and ash are as significant as its protein content and composition. Thus, when evaluating the technofunctional properties of bee pollen, it is necessary to consider the effects of all surfactant substances in bee pollen, as well as their increasing and decreasing interactions with other compounds individually and collectively.

The most important of the technofunctional properties is considered to be protein solubility, because it affects emulsification properties, gelation properties and foaming capacity and stability. Although, bee pollen contains low protein compared to other protein sources, it has high protein solubility.

However, bee pollen proteins have better oil absorbing capacity than water absorbing capacity, good emulsification properties and foam suppression activity compared the other protein sources (soy flour, black gram kidney bean flour). All these technofunctional properties are mainly due to the presence of surfactants and interactions with other pollen components.

Although the nutritional value and therapeutic effects of bee pollen proteins are known, in the literature studies have not include enough data about technofunctional properties of bee pollen proteins. Therefore, further research should be conducted on its possible use in functional food products for their technofunctional properties.

\section{DERLEME / REVIEW}

Conclusion: Bee pollen proteins and their technical use as a functional food depends on its physicochemical and technofunctional properties. However, past studies in this field are very limited in the literature. For this reason, more studies should be studied on the proteins of bee pollen and its technological properties. Especially, the using of bee pollen proteins in the food industry, it needs to some new technofunctional properties are determined. Thus, it is possible to predict the interaction of bee pollen with food and the changes during processing with the findings obtained. In conclusion, this review offers an opportunity to the food industry to determine the functional properties of bee pollen proteins and identify novel food uses to develop ingredients.

\section{GíRiş}

Polen, kovana bal getiren işçi arılar tarafından çiçeğin stamenlerinden toplanmakta, nektar veya bal ile nemlendirilerek arının arka bacaklarında biriktirilmektedir (Krell 1996). Bal arıları, bal özlerini toplarken vücutlarına farkında olmadan yapışan polenler ile bitkilerde tozlaşmayı ve bal arılarının beslenmesi için gerekli olan polenin toplanmasını sağlarlar (Erdoğan ve Dodoloğlu 2005). Bir arı, vücut ağırlığı ile orantılı olarak, kovana tek seferde 15-45 $\mathrm{mg}$ polen taşıyabilmektedir. Kolonilerin yıllık polen üretimi ise koloni büyüklüğü ve çevresel şartlara (iklim, bitki örtüsü vb.) göre farklılaşmaktadır (Dreller ve Tarpy 2000). Kovanda depolanan polenler koyuldukları gözlerde üzerine bal veya sıvı eklenerek muhafaza edilir.

Endüstriyel anlamda insan tüketimine sunulması istenen polenin, toplanması kadar kurutulması ve saklama koşulları da besin bileşimi açısından önemlidir. Kurutulacak olan polenlerin önceki yıllarda güneşte kurutulması kabul edilirken bu kurutma yönteminin polenin sahip olduğu besin içeriğinde azalmaya neden olduğu belirlenerek yöntemin kullanımından vazgeçilmiştir (Aydın 2016).

Kurutulmuş halde \%6-8 nem içeriğine sahip olan polenlerde bu oranın üstüne çıkılması veya altına inilmesi halinde bozulma ve besin değerinde kayıplar meydana gelmektedir (İnci 1999). Bu nedenle tüketilecek olan polenin hem protein içeriğinin hem de diğer besin bileşenlerinin zarar görmemesi için uygun kurutma teknikleri tercih edilmelidir. Polen kurutma işleminin, sıcaklık (36- 


\section{DERLEME / REVIEW}

$45^{\circ} \mathrm{C}$ ) kontrolünün sağlandığı kurutma dolaplarında yapılması alternatif kurutma yöntemlerinden biridir, ancak kurutma işlemi sonrasında polenler yabancı maddelerden temizlenmelidir.

Paketlenen polenlerin içerisinde kalan hava boşluklarının $\mathrm{CO}_{2}$ (karbondioksit) ile doldurulması ve polen içindeki havanın vakumlanarak çıkarılması ile güve kelebeği ve benzeri zararlılara ait yumurtalarının vereceği zarar önlenebilir; polenler bu şekilde uzun süre bozulmadan saklanabilir (Aydın 2016).

Kurutulan ve temizlenen polenlerin raf ömrü sıcaklıkla ters orantılı olarak değişmektedir. Örneğin oda sıcaklığında $1-2$ ay, $5^{\circ} \mathrm{C}$ 'da $1 \mathrm{yıl},-15^{\circ} \mathrm{C}$ 'da ise besin değerinde önemli bir kayıp yaşanmadan uzun süre depolanabilmektedir. Ayrıca raf ömrünü arttırmak için polenlerin koyu renkli cam kaplara konulması, ışıksız ve serin yerlerde muhafaza edilmesi avantaj sağlamaktadır. Geliştirilen teknolojiler ve yeni yöntemlerle polen farklı şekillerde muhafaza edilmektedir. Örneğin; polen toz şekerle karıştıııarak (Genç ve Dodoloğlu 2002), mikrodalgada kurutularak (Kanar 2017), vakum altında dondurularak (Kumova ve Korkmaz 1998), dondurularak (Kutlu vd. 2015) ve sicak hava ile kurutularak (Aydın 2016) muhafaza edilmektedir.

Polenin sahip olduğu besin bileşenleri toplandığı bölgeye bağlı olarak farklılık göstermektedir. Bu nedenle polenin besin değerleri için tam bir standart olmasa da polen, yaklaşık \%4-15 su, \%7,5-40 protein, \%15-82 şeker, \%1,3-7 lipid, \%1-3,5 vitamin ve mineral içermektedir (Almeida-Muradian vd. 2005, Stanciu vd. 2011, Kostić vd. 2015). Arı poleni besin değeri yanında sahip olduğu biyolojik aktivite sayesinde; antitümör, hemopreventif/kemoprotektif, antimikrobiyal, antifungal, antioksidan, antiradyasyon ve anti-inflamatuar özelliklerle insan sağlığı üzerine olumlu etkiler göstermiştir (Kinsella ve Melachouris 1976, Pascoal vd. 2014).

Arı poleni tek başına tüketilebildiği gibi diğer gıda ürünlerinin içerisine katılarak da tüketicilerin tercihine sunulmaktadır. Ancak arı poleninin diğer gıdalarla olan etkileşimlerine ait fazla veri bulunmamaktadır. Bu nedenle, endüstride kullanımının yaygınlaşmasını ve yeni teknofonksiyonel özelliklerinin tespit edilmesini sağlamak amacı ile arı poleninin proteinleri ve teknolojik özellikleri hakkında daha fazla çalışma yapılmalıdır. $\mathrm{Bu}$ çalışmada öncelikle arı poleni proteinlerinin çözünürlük, emülsifiye etme, köpürme özellikleri, su ve yağ tutma kapasitesi gibi teknofonksiyonel özellikleri değerlendirilecektir. Böylelikle elde edilen bulgularla arı poleninin gıdalarla etkileşimi ve işleme sırasındaki değişikliklerin öngörülmesine olanak sağlanabileceği düşünülmektedir.

\section{Arı Poleni Proteinleri}

Arı poleninin içeriğinde bulunan aminoasitlerdeki farklılıklar, arıcılığın yapııdığı bölgeye, mevsime ve botanik çeşitliliğe göre değişiklik göstermektedir. Genel olarak arı polenlerinin çeşitli kombinasyonlarda esansiyel olan ve olmayan aminoasit içeriğine sahip olduğu bilinmektedir (Tablo 1) (Paramas vd. 2006, Mărgăoan vd. 2010, Yang vd. 2013, Gardana vd. 2018, Negrao ve Orsi, 2018, Thakur ve Nanda 2018, Taha vd. 2019, ZuluagaDomínguez vd. 2019, Al-Kahtani vd. 2020, Sommano vd. 2020, Thakur ve Nanda 2020, Bayram 2021, Bayram vd. 2021). Alınan polen örnekleri üzerinde yapılan çalışmalarda İspanya, İtalya ve Kolombiya'dan (Gardana vd. 2018) prolin ve arjinin; Hindistan'da (Thakur ve Nanda 2018) glutamik asit, aspartik asit, prolin, lösin, alanin, lizin; Brezilya'da (Negrao ve Orsi, 2018) prolin, glutamik asit, aspartik asit, lizin ve Türkiye'de (Bayram 2021, Bayram vd. 2021) prolin, asparajin ve aspartik asit başlıca aminoasit kaynaklarını oluşturmaktadır. Ancak mevsimsel değişiklikler polenlerin bileşimindeki aminoasit kombinasyonunun farklılaşmasına sebep olduğu gibi bu kombinasyondaki baskın aminoasitlerin değişmesine de yol açmaktadır.

Esansiyel olmayan bir aminoasit olan prolin, bal arıları için uçuş enerjisi kaynağı olmasından dolayı, Dünya üzerinde toplanan polenlerde çoğu zaman baskın aminoasit olarak karşımıza çıkmaktadır. Prolinin baskın olarak görülmediği polenlerin toplandığı bölgelerde, Türkiye'de yetiştirilen deli baldan elde edilen kovanlardan toplanan Rhododendron ponticum polenlerde olduğu gibi, botanik özelliklerden dolayı baskın aminoasit (asparajin) değişebilmektedir (Bayram 2021). Ancak prolin baskınlığını kaybetse de polen bileşiminin önemli bir kısmını oluşturmaktadır.

İçeriğindeki kıymetli bileşenler nedeniyle arı poleni genellikle besin takviyesi olarak tüketilmektedir. Günümüzde yapılan araştırmalarla, arı poleni sadece besleyici ve tedavi edici özellikleri ile gıda takviyesi olarak kullanılmamakta, aynı zamanda ürün kalite özelliklerini geliştirmek için fonksiyonel bir bileşen olarak geliştirilmeye çalışılmaktadır. 
Tablo 1 Arı poleni içeriğinde bulunan esansiyel ve esansiyel olmayan aminoasitler

\begin{tabular}{llll}
\hline Esansiyel aminoasitler & & \multicolumn{2}{l}{ Esansiyel olmayan aminoasitler } \\
\cline { 1 - 1 } \cline { 3 - 3 } Histidin & Alanin & Gama-aminobütirik asit \\
İözin & Arjinin & 3-Amino izobütirik asit \\
Lözin & Aspartik asit & Aminoadipik asit \\
Lizin & Asparajin & Etanolamin \\
Metionin & Sistein & Glutamin \\
Fenilalanin & Glisin & Sarkozin \\
Treonin & Glutamik asit & Homositrülin \\
Triptofan & Prolin & Sitrülin \\
Valin & Serin & Ornitin \\
& Taurin & Norlösin \\
& Tirozin & Homoserin \\
& g-Aminobütirik asit & Sarkozin \\
\hline
\end{tabular}

Yapılan çalışmalarda arı poleni, fermente sütlü içeceklere eklendiğinde antimikrobiyal aktivite sergilemiştir. Benzer şekilde asidofilus sütü ve probiyotik yoğurda arı poleni eklenmesi, duyusal özellikleri etkilemeden probiyotik canlılığı ve içecek viskozitesini ve yağ seviyesinden bağımsız olarak laktik asit üretimini arttırmıştır (Glušac vd. 2015).

Fırın ürünlerinde arı poleninin kullanımı, Krystyjan vd. (2015) tarafından bisküvi şeklindeyken ve Conte ve ark. (2018) tarafından glutensiz ekmek şeklindedir. Hazırlanan bisküvilerde artan arı poleni oranı ile birlikte protein, şeker, kül, lif, polifenoller ve antioksidan potansiyeli önemli ölçüde yükselmiştir, ancak lezzet bu durumdan olumsuz etkilenmiştir (Krystyjan vd. 2015). Ekmekte ise tekno-fonksiyonel özelliklerde bir gelişme, bayatlama oranında azalma ve ekmeğin genel organoleptik kabul edilebilirliğinde bir artış elde edilmiştir.

Ayrıca yapılan son araştırmalarda, arı poleni yüksek antioksidan potansiyeli ve fenolik bileşik içeriğine sahip olması nedeniyle pudinglerde (Anjos vd. 2019), yağ oksidasyonunu engellemek amacıyla domuz sosislerinde (de Florio Almeida vd. 2017), diğer et ürünlerinde (Novaković vd. 2021) ve içeceklerde (Zuluaga vd. 2016) kullanılmasıyla olumlu sonuçlar elde edilmiştir.

Arı poleninin gıdalarda kullanımına ek olarak bileşiminde yer alan aminoasitlerle yapılan bir çalışmada kışlık buğday ununa prolin ve glutamin ilavesinin ekmek hamurunun fonksiyonel özellikleri üzerine etkileri incelenmiştir. Prolin veya glutamin ilavesi, yumuşak buğday hamuru ve ekmek özelliklerinde önemli gelişmeler sağlamazken, glutamin ve prolin kombinasyonu sinerjik etki göstererek, hamur ve ekmek özelliklerini iyileştirmiştir (Fermin vd. 2005).

Bu çalışmalar, diğer ürünlerde arı poleni kullanımı içi umut vermekte ve daha fazla araştırıması için bir temel sağlamaktadır. Ancak arı poleninin gıda ürünlerindeki uygulamalarında, içerisine ilave edileceği ürünün besin değeri, biyoaktif bileşen içeriği, tekno-fonksiyonellikleri, organoleptik özellikleri ve gıda güvenliği açısından kapsamlı bir şekilde incelemelidir.

Arı poleninin teknik açıdan fonksiyonel gıda maddesi olarak kullanımı; fiziksel, kimyasal ve teknofonksiyonel özelliklerine bağlıdır. İşlenmiş gıda ürünlerinin çoğu, gıda biyopolimeri, proteinler, polisakaritler ve çeşitli partikül türleri içeren çok bileşenli koloidal sistemlerdir (Schimidt 1997). Bu nedenle gıda işlemede en çok ilgi gören teknofonksiyonel özellikler arasında çözünürlük, emülsiyon oluşumu ve stabilizasyonu, köpük oluşumu ve stabilizasyonun yanı sıra su ve yağ tutma kapasitesi de bulunur. Arı polenlerinin bu özellikleri üzerine yapılan çalışmalar sınırı kalsa da 
yapılan çalışma ile konuya dikkat çekilmesi amaçlanmıştır.

\section{Arı Poleninin Fonksiyonel Özellikleri}

\section{Protein çözünürlüğü}

Protein çözünürlüğü, emülsifikasyon, köpürme ve jelasyon gibi diğer özellikleri etkilediğinden, teknofonksiyonel özelliklerden en önemlisi olarak kabul edilmektedir (Lee vd. 2003, Kanar 2017). Protein çözünürlüğü, protein kompozisyonu ve konformasyonun yanı sıra proteinler ve diğer bileşenler (tuzlar, lipidler, karbonhidratlar ve fenolik bileşikler) arasındaki etkileşimler vasıtasıyla belirlenmektedir. Protein çözünürlüğünü etkileyen faktörlerden bir diğeri de proteinlerin moleküler ağırlıklarıdır. Düşük (10-25 kDa) ve orta (25-50 kDa) molekül ağırlıklı proteinlerin, yüksek molekül ağırlıklı proteinlere (50-80 kDa) göre protein çözünürlüğü daha yüksektir.

Arı poleni protein çözünürlüğü ortalama 11,22ะ6 g/100 g (84.91 to 87.56\%)'dır (Kostić vd. 2015). Bu değerler, pH 7'deki düşük çözünürlüklü ticari soya proteini ürünleri (unlar, konsantreler ve izolatlar) için elde edilen değerlerle karşılaştırıldığında (Lee vd. 2003) ticari soya proteini ürünlerinin yaklaşık 20 g/100 g veya daha düşük çözünürlüğe sahip olduğu görülmektedir. Çözünürlüğü etkileyen bir diğer önemli faktör de ıslanabilirlik ve dağılabilirliktir. Bu konuda arı poleni ile ilgili çalışmalarda ıslanabilirlik 285.67-1909.46s ve dağılabilirlik 34.10 ve $51.06 \%$ olarak değişirkenlik göstermektedir. Bu değerler keçi sütünden elde edilen süt tozu (Islanabilirlik, 418.80594.00s; dağılabilirlik, \%78.38-84.11) ile kıyaslandığında arı poleninin daha yüksek ıslanabilirlik ve daha düşük dağılabilirlik özelliğine sahip olduğunu göstermektedir (Reddy ve diğerleri, 2014).

\section{Emülsiyon yapıcı özellikler}

Gıdalardaki yapı ve yapıları oluşturan birimler arasındaki emülsiyonlar önemli bir rol oynamaktadır. Emülsifiyer bu bileşenler gıdaya ağızda arzu edilen hissi özellikleri kazandırmakta ve mayonez, kahve, krema likörleri, bazı meyve içecekleri ve et ürünlerinin birçoğunda ve diğer birçok gıda ürününde yapının oluşumunda anahtar bileşenler olarak karşımıza çıkmaktadır (Dalgleish 2004).

Proteinler, temel gıda emülgatörlerinden biri olarak kabul edilmesine rağmen, lipidler gibi diğer bileşenler de iyi emülsiyon yapıcılar gibi davranır. Ayrıca arı poleni; potasyum ve kalsiyum gibi mineralleri, pektin ve nişasta gibi dengelenmiş veya arayüzey malzeme ile etkileşime girebilen yüklü veya yüklenmemiş polisakaritleri içermektedir (Kostić vd. 2015). Bu nedenle, emülsiyon kararlılığı ve aktivitesi ile protein çözünürlüğü veya çözünebilir protein içeriği arasındaki ilişki arı poleni numunelerindeki birçok yüzey aktif bileşen arasındaki varlığın ve etkileşimlerin sonucunda ortaya çıkabilmektedir.

Sırbistanda yapılan bir çalışmada arı poleni proteinlerinin emülsiyon yapıcı özellikleri; ESI (emülsiyon stabilite indeksi) ve $\mathrm{EAI}$ (emülsiyon aktivite indeksi) araştırılmış, EAI ortalama $15,71 \pm 3,29 \mathrm{~m}^{2} \mathrm{~g}^{-1}, \mathrm{ESI}$ ise ortalama $31,85 \pm 8,94$ dakika değerinde bulunmuştur. (Kostić vd. 2015). Yapılan diğer bir çalışmada arı polen çeşitliliği emülsiyon özellikleri açısından değerlendirilmiş ve hindistan cevizi poleni emülsiyon aktivitesi $\% 46.76 \pm 0.83 \mathrm{~m}^{2} \mathrm{~g}-1$, stabilitesi $\% 26.32 \pm 0.31$ dakika, kolza poleni emülsiyon aktivitesi \%44.83 $\pm 0.53 \mathrm{~m}^{2} \mathrm{~g}^{-1}$ ve stabilitesi \%21.62 \pm 0.37 dakika olarak belirlenmiştir (Thakur ve Nanda, 2020). Bu sonuçlara bakıldığında, arı poleninin emülsiyon aktivitesi, karnabahar unu (\%50.948 \pm 2.06$)$, şalgam unu (\%46.108 \pm 2.18$)$, buğday unu (\%43.141 \pm 2.25$)$, pirinç unu (\%41.48 \pm 1.842$)$, maş fasülyesi (\%41.17士1.021) gibi ürünlerle yaklaşık aynı değer aralığındayken, patates unu (\%39.05 \pm 4.984$)$, börülce unu (\%25.213 $\$ 1.37)$ ve meksika fasulyesi unu (\%21.749 \pm 1.70 ) gibi protein içerikli ürünler için elde edilen sonuçlardan daha iyi düzeydedir (Kumar vd. 2017, Chandra ve Samsher 2013).

Arı poleninin emülsiyon stabilitesine bakıldığında; şalgam unu $(\% 42.460 \pm 2.12)$, patates unu

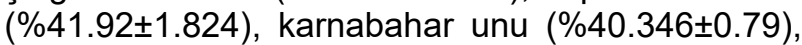
buğday unu (\%38.38 \pm 4.785$)$, maş fasülyesi $(\% 37.95 \pm 2.362)$ ve pirinç unu $(\% 37.31 \pm 5.407)$ gibi ürünlerden daha düşük meksika fasulyesi unu

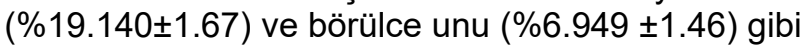
protein içerikli ürünlerden daha yüksek bir değere sahip olduğu görülmektedir (Kumar vd. 2017, Chandra ve Samsher 2013). Bu değerler arı polenlerinin iyi emülsifiye edici özelliğe sahip olduğunu göstermektedir (Heywood vd. 2002). Ayrıca emülsifiye edici özelliklerdeki bu farklılıklar; sıvı damlacık boyutu ve dağılımına, protein özelliklerine (hidrofobiklik, konformasyon, konsantrasyon ve çözünürlük), çözücü koşullarına (tuzlar, pH ve sıcaklık), faz hacim oranına ve sürekli faz viskozitesine göre değişkenlik göstermektedir (Avramenko vd. 2013). 


\section{Köpürme özellikleri}

Ekmek, kek, dondurma gibi gıda ürünlerinin işleme sırasında veya sonrasında, yapısının ve dokusunun oluşması ve korunması için havaya ihtiyaç duyulmaktadır. Arı poleni köpük stabilitesi (\%17.5020.00) ve kapasitesi (\%6.21-8.69) açısından düşük oranlara sahiptir. Bu nedenle köpük yapıcı özellik gerektiren ürünlerde tercih edilmezler (Kostić vd. 2015). Arı poleni, fındık unu proteinleri ile karşılaştırıldığında kapasitesinin (\%8) aynı değerlerde, fakat stabilitesinin fındık proteinlerine göre daha yüksek olduğu gözlenmiştir (Tatar vd. 2015). Ancak yumurta albümini, kajudan elde edilen protein izolatları ile kıyaslandığında bu değerler oldukça düşük kalmaktadır (Neto vd. 2001).

Köpük yapıcı özelliklerin bulunmaması, arı poleni bileşiminde bulunan yüzey aktif lipidlerden kaynaklanabilir. Lipidler proteinlerden daha yüksek yüzey aktivitesi nedeniyle köpük stabilitesinde azalmaya neden olmaktadır (Phillips 2013). Ayrıca fosfolipidlerin ve lipoproteinlerin köpük baskılayıcı ajanlar olduğu bilinmektedir (Lee vd. 2003). Liang vd.'nin yaptığı çalışmada (2013), polen tanelerinin lipid profilinin analiz edilmesiyle polar lipidlerin büyük kısmının membrana bağlı fosfolipitler, fosfatidilkolin ve fosfatidilserin olduğu tespit edilmiştir. Böylelikle ortaya çıkan düşük köpürme ve köpük baskılayıcı özelliği ile arı poleni köpürme özelliklerinin istenmediği gıda bileşeni olarak kullanılabilir.

\section{Su tutma kapasitesi (STK)}

Su tutma kapasitesi, ürünün nemli olması gibi belirli ürün özellikleri için önemlidir. Yüksek su tutma kapasitesi olan gıdalar, özellikle depolama sırasında gıda ürünlerini kırılgan ve kuru hale getirebilir. Arı poleninin su tutma kapasitesi; yapılan çalışmalarda

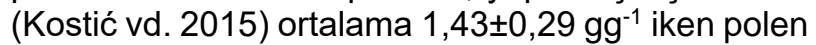
cinsine göre kişniş poleninde $0.47 \pm 0.05 \mathrm{gg}^{-1}$ ve hindistan cevizi poleninde $0,72 \pm 0,08 \mathrm{gg}^{-1}$ olarak değişmektedir. Bu değerler, meksika fasülyesi için elde edilen değerlere göre daha düşüktür (Wani vd. 2013). Ancak soya fasülyesi proteininkiyle benzer şekildedir (Acuna vd. 2012).

Arı poleninin su tutma kapasitesini etkileyen başlıca bileşenler, kutup grupları içerdikleri için polar veya yüklü yan zincir ve çözünmeyen karbonhidratlar gibi hidrofilik kısımlar içeren çözünmeyen proteinlerdir. Ayrıca, bu moleküller, kılcal eylemler yoluyla su moleküllerini bağlayabilen üç boyutlu yapılara sahiptir. Bu nedenle, kutupsal ve yüklü bölgelerdeki lipidlerin daha iyi su tutma kapasitesi kazanmada katkıda bulunabileceği belirtilmelidir.

\section{Yağ tutma kapasitesi (YTK)}

Herhangi bir gıda bileşiminin yağ tutma kapasitesi, gıda uygulamaları için önemlidir. Çünkü lipidler, lezzet tutucu ve ağızdaki tadı artırıcı etkiye sahiptir (Ötles 1995). Çözünmeyen moleküllerin hidrofobik kısımlarının bulunması YTK için oldukça önemlidir. Arı poleninin YTK'sı için ortalama değeri 2,49 $\pm 0,56$ $\mathrm{gg}^{-1}$ (Kostić vd. 2015) iken, yapılan diğer çalışmalarda kişniş poleninde $1.31 \pm 0.11 \mathrm{~g} / \mathrm{g}$ ve hindistan cevizi poleninde $2.13 \pm 0,20 \mathrm{~g} / \mathrm{g}$ olarak değişmektedir. Bu değerler meksika fasulyesi (2,2$2,3 \mathrm{gg}^{-1}$ ) (Wani vd. 2013) ve soya fasulyesi $\left(1,43 \mathrm{mlg}^{-}\right.$ 1) (Acuna vd. 2012) için elde edilen değerlerden daha yüksektir.

Arı polenlerinin YTK'sına önemli oranda katkıda bulunan ana bileşen, polenin ana bileşenini oluşturan sporopollenin olabilir. Sporopollenin, polen kuru ağırlığının \%20'sinden fazlasını oluşturan yağ asidi-lignin benzeri kompleks bir polimerdir (Stanley ve Linskens 2012). Sporopolleninin hidrofobik kısmı ve hidrofobik kalıntılara sahip olan diğer çözülmeyen bileşenler arı polenlerinin YTK'sını artırabilir. Yapılan çalışmalar bu anlamda incelendiğinde arı poleni proteinlerinin, hidrasyon özelliklerine göre daha iyi lipofilik özellik gösterdiği belirlenmiştir (Kostić vd. 2015).

\section{SONUÇ VE ÖNERILER}

Eski çağlardan beri çiçek poleni besin yararları için insanlar tarafından kullanılmıştır. Günümüzde besin takviyesi olarak sıkça tüketilen arı poleninden gıda işlemede de fonksiyonel özelliklerinden faydalanılabilir. Arı poleni diğer protein kaynakları ile kıyaslandığında düşük protein içermesine karşın yüksek protein çözünürlüğü, su tutma kapasitesinden daha iyi yağ tutma kapasitesi, iyi emülsiyonlaşma özellikleri ve köpük baskılama aktivitesine sahiptir. Bütün bu teknofonksiyonel özellikler temel olarak yüzey aktif bileşenlerin varlığı ve diğer polen bileşenleriyle olan etkileşimlere bağlı olarak ortaya çıkmaktadır.

Arı poleninin teknofonksiyonel özellikleri için protein içeriği ve bileşimi kadar karbonhidratların, lipitlerin, külün içeriği ve bileşimi de önemlidir. Böylece arı poleninin teknofonksiyonel özellikleri değerlendirilirken arı polenlerindeki tüm yüzey aktif 


\section{DERLEME / REVIEW}

bileşenlerin özelliklerini, bireysel ve toplu olarak diğer bileşiklerle olan artırıcı ve azaltıcı etkileşimlerini de göz önünde bulundurmak gerekmektedir.

Arı poleni, besleyici değerinin yüksek olmasından dolayı insan sağlığının korunması ve iyileştirilmesi amacıyla yaygın olarak tüketilmeye başlanmıştır. İnsan sağlığı üzerindeki takviye edici etkileri bilinse de teknolojik açıdan gıda ürünlerinde, olası kullanımıyla ilgili daha ileri araştırmalar yapılmalıdır. $\mathrm{Bu}$ araştırmalar yapılırken arı poleninin; besleyici değeri, sağlık etkileri ve belirli teknofonksiyonel özelliklerin kombinasyonunun çalışılmasının gıda sektöründe büyük bir potansiyele kapı aralayacağı düşünülmektedir.

Mali kaynak: Mali kaynak sağlayan bir kurum bulunmamaktadır.

Etik belgesi: Etik belgesi gerekli değildir.

\section{KAYNAKLAR}

Acuna, SPC., Gonzalez, JHG., Torres, IDA. 2012. Physicochemical characteristics and functional properties of vitabosa (mucuna deeringiana) and soybean (glycine max). Ciencia $e$ Tecnologia di Alimentos, 32(1), 98e105, doi.org/10.1590/S0101-20612012005000007.

Almeida-Muradian, LB., Pamplona, LC., Coimbra, S., Barth, OM. 2005. Chemical composition and botanical evaluation of dried bee pollen pellets. Journal of Food Composition and Analysis, 18(1), 105-111, doi.org/10.1016/j.jfca.2003.10.008.

Al-Kahtani, S. N., Taha, E. K., Khan, K. A., Ansari, M. J., Farag, S. A., Shawer, D. M., Elnabawy, E. S. M. 2020. Effect of harvest season on the nutritional value of bee pollen protein. PloS one, 15(12), e0241393, doi.org/10.1371/journal.pone.0241393.

Anjos, O., Fernandes, R., Cardoso, S. M., Delgado, T., Farinha, N., Paula, V., Carpes, S. T. 2019. Bee pollen as a natural antioxidant source to prevent lipid oxidation in black pudding. LWTFood Science and Technology, 111, 869-875, doi.org/10.1016/j.Iwt.2019.05.105.

Avramenko, N. A., Low, N. H., Nickerson, M. T. 2013. The effects of limited enzymatic hydrolysis on the physicochemical and emulsifying properties of a lentil protein isolate.
Food Research International, 51(1), 162-169, doi.org/10.1016/j.foodres.2012.11.020.

Aydın, G. 2016. Farklı kurutma yöntemleri ve farklı özütleme çözgenlerinin arı poleninin antioksidan kapasitesi ve fenolik içeriği üzerine etkisi (Yayımlanmamış yüksek lisans tezi). Ordu Üniversitesi Fen Bilimleri Enstitüsü, Ordu.

Bayram, N. E., Gercek, Y. C., Çelik, S., Mayda, N., Kostić, A. Ž., Dramićanin, A. M., Özkök, A. 2021. Phenolic and free amino acid profiles of bee bread and bee pollen with the same botanical origin-similarities and differences. Arabian Journal of Chemistry, 14(3), 103004, doi.org/10.1016/j.arabjc.2021.103004.

Bayram, N. E. (2021). Vitamin, mineral, polyphenol, amino acid profile of bee pollen from Rhododendron ponticum (source of "mad honey"): nutritional and palynological approach. Journal of Food Measurement and Characterization, 15(3), 2659-2666, doi.org/10.1007/s11694-021-00854-5.

Chandra, S., Samsher. 2013. Assessment of functional properties of different flours. African Journal of Agricultural Research, 8(38), 48494852, doi.org/10.5897/AJAR2013.6905.

Conte, P., Del Caro, A., Urgeghe, P. P., Petretto, G. L., Montanari, L., Piga, A., Fadda, C. 2020. Nutritional and aroma improvement of glutenfree bread: is bee pollen effective?. LWT-Food Science and Technology, 118, 108711, doi.org/10.1016/j.Iwt.2019.108711.

Dalgleish, DG. 2004. Food emulsions: their structures and properties. Food Emulsions, 4, $1-44$.

de Florio Almeida, J., dos Reis, A. S., Heldt, L. F. S., Pereira, D., Bianchin, M., de Moura, C., Carpes, S. T. 2017. Lyophilized bee pollen extract: A natural antioxidant source to prevent lipid oxidation in refrigerated sausages. LWT-Food Science and Technology, 76, 299-305, doi.org/10.1016/j.Iwt.2016.06.017.

Dreller, C., Tarpy, DR. 2000. Perception of the pollen need by foragers in a honeybee colony. Animal behaviour, 59(1), 91-96, doi.org/10.1006/anbe.1999.1303.

Erdoğan, Y., Dodoloğlu, A. 2005. Balarısı (Apis mellifera L.) kolonilerin yaşamında polenin önemi. Uludağ Arıcılık Dergisi, 5(2), 79-84. 
Fermin, B. C., Hahm, T. S., Radinsky, J. A., Kratochvil, R. J., Hall, J. E., Lo, Y. M. 2005. Effect of proline and glutamine on the functional properties of wheat dough in winter wheat varieties. Journal of Food Science, 70(4), E273E278, 2621.2005.tb07183.x.

Gardana, C., Del Bo, C., Quicazán, M. C., Corrrea, A. R., Simonetti, P. 2018. Nutrients, phytochemicals and botanical origin of commercial bee pollen from different geographical areas. Journal of Food Composition and Analysis, 73, 29-38, doi.org/10.1016/j.jfca.2018.07.009.

Genç, F., Dodoloğlu, A. 2002. Arıcılığın Temel Esasları. Atatürk Üniv. Zir. Fak., Ders Yayınları No: 166, Erzurum.

Glušac, J. R., Stijepić, M. J., Milanović, S. D., Đurđević-Milošević, D. M. 2015. Physicochemical properties of honeybee pollen enriched acidophilus milk and probiotic yoghurt. Acta Periodica Technologica, (46), 45-54, doi.org/10.2298/APT1546045G.

Heywood, AA., Myers, DJ., Bailey, TB., Johnson, LA. 2002. Functional properties of low-fat soy flour produced by an extrusion-expelling system. Journal of the American Oil Chemists' Society, 79(12), 1249-1253, doi.org/10.1007/s11746-002-0635-y.

İnci, A., 1999. Ana Arı Üretimi. Önder Matbaacılık Ltd. Şti. Ankara. 131s.

Lee, KH., Ryu, HS., Rhee, KC. 2003. Protein solubility characteristics of commercial soy protein products. Journal of the American Oil Chemists' Society, 80(1), 85-90, doi.org/10.1007/s11746-003-0656-6.

Kanar, Y. 2017. Farklı Kurutma Yöntemlerinin Arı Poleninin Fizikokimyasal Özellikleri ve Antioksidan Aktivitesi Üzerine Etkisi (Yayımlanmamış yüksek lisans tezi). Ordu Üniversitesi Fen Bilimleri Enstitüsü, Ordu.

Kinsella, JE., Melachouris, N. 1976. Functional properties of proteins in foods: a survey. Critical Reviews in Food Science \& Nutrition, 7(3), 219280, doi.org/10.1080/10408397609527208.

Kostić, AŽ., Barać, MB., Stanojević, SP., MilojkovićOpsenica, DM., Tešić, ŽL., Šikoparija, B.,

\section{DERLEME / REVIEW}

Radišić, P., Prentoviç, M. Pešić, MB. 2015. Physicochemical composition and technofunctional properties of bee pollen collected in Serbia. LWT-Food Science and Technology, 62(1), 301-309, doi.org/10.1016/j.lwt.2015.01.031

Krell, R. 1996. Value-Added Products From Beekeeping. FAO Agricultural Services Bulletin, 124, 409p.

Krystyjan, M., Gumul, D., Ziobro, R., Korus, A. 2015. The fortification of biscuits with bee pollen and its effect on physicochemical and antioxidant properties in biscuits. LWT-Food Science and Technology, 63(1), 640-646, doi.org/10.1016/j.Iwt.2015.03.075.

Kumar, K., Chandra, S., Samsher, N. C., Singh, J., Kumar, M. 2017. Functional properties of food commodities (wheat, kidney bean, cowpea, turnip, cauliflower) flours. Int J Crop Sci, 5, 1199-1202.

Kumova, U., Korkmaz, A. 1998. Bal arıları (Apis mellifera $L$.)'nın topladığı polenin özellikleri ve kullanım olanakları. Teknik Arıcılık, 61, 210.Kutlu, N., İşci, A., Demirkol, ÖS. 2015. Thin layer drying models in food systems. Gıda, 40(1): 39-46.

Lee, K. H., Ryu, H. S., Rhee, K. C. 2003. Protein solubility characteristics of commercial soy protein products. Journal of the American Oil Chemists' Society, 80(1), 85-90, doi.org/10.1007/s11746-003-0656-6.

Liang, M., Zhang, P., Shu, X., Liu, C., Shu, J. 2013. Characterization of pollen by MALDI-TOF lipid profiling. International Journal of Mass Spectrometry, $\quad 334, \quad 13-18$, doi.org/10.1016/j.ijms.2012.09.007.

Mărgăoan, R., Mărghitaş, L., Dezmirean, D., Mihai, C., Bobiş, O. 2010. Bee collected pollen. General aspects and chemical composition. Bulletin UASVM Animal Science and Biotechnologies, 67(1-2), 1-6.

Neto, V. Q., Narain, N., Silva, J. B., Bora, P. S. 2001. Functional properties of raw and heat processed cashew nut (Anacardium occidentale, L.) kernel protein isolates. Food/Nahrung, 45(4), 258-262. 
Negrao, A. F., Orsi, R. O. 2018. Harvesting season and botanical origin interferes in production and nutritional composition of bee pollen. Anais da Academia Brasileira de Ciências, 90, 325-332, doi.org/10.1590/0001-3765201720150192.

Novaković, S., Djekic, I., Pešić, M., Kostić, A., Milinčić, D., Stanisavljević, N., Tomasevic, I. 2021. Bee pollen powder as a functional ingredient in frankfurters. Meat Science, 182, 108621.

DOI: https://doi.org/10.1016/j.meatsci.2021.108621.

Ötles, S. 1995. Bal ve Bal Teknolojisi (Kimyası ve Analizleri). Alaşehir Meslek Yüksek Okulu Yayınları.

Paramás, AMG., Bárez, JAG., Marcos, CC., GarcíaVillanova, RJ., Sánchez, JS. 2006. HPLCfluorimetric method for analysis of amino acids in products of the hive (honey and bee-pollen). Food Chemistry, 95(1), 148-156. DOI: https://doi.org/10.1016/j.foodchem.2005.02.00 8.

Pascoal, A., Rodrigues, S., Teixeira, A., Feás, X., Estevinho, L.M. 2014. Biological activities of commercial bee pollens: Antimicrobial, antimutagenic, antioxidant and antiinflammatory. Food and Chemical Toxicology, 63, 233-239, doi.org/10.1016/j.fct.2013.11.010.

Phillips, LG. 2013. Structure-function properties of food proteins. Academic Press.Reddy, R. S., Ramachandra, C. T., Hiregoudar, S., Nidoni, U., Ram, J., Kammar, M. (2014). Influence of processing conditions on functional and reconstitution properties of milk powder made from Osmanabadi goat milk by spray drying. Small Ruminant Research, 119(1-3), 130-137, doi.org/10.1016/j.smallrumres.2014.01.013.

Schimidt, JO. 1997. Bee Product: Chemical Composition and application. International Conference on Bee product Properties, Applications and Apitheraphy. P 15-26. İsrail.

Sommano, S. R., Bhat, F. M., Wongkeaw, M., Sriwichai, T., Sunanta, P., Chuttong, B., Burgett, M. 2020. Amino Acid Profiling and Chemometric Relations of Black Dwarf Honey and Bee Pollen. Frontiers in Nutrition, 7, 283, doi.org/10.3389/fnut.2020.558579.

Stanciu, OG., Mărghitaş, LA., Dezmirean, D., Campos, MG. 2011. A comparison between the mineral content of flower and honeybee collected pollen of selected plant origin (Helianthus annuus L. and Salix sp.). Rom Biotechnol Lett, 16(4), 6291-6296.

Stanley, RG., Linskens, HF. 2012. Pollen: biology biochemistry management. Springer Science \& Business Media, pp: 310. Berlin.

Taha, E. K. A., Al-Kahtani, S., Taha, R. 2019. Protein content and amino acids composition of beepollens from major floral sources in Al-Ahsa, eastern Saudi Arabia. Saudi Journal of Biological Sciences, 26(2), 232-237, doi.org/10.1016/j.sjbs.2017.06.003.

Tatar, F., Tunç, M. T., Kahyaoglu, T. 2015. Turkish Tombul hazelnut (Corylus avellana L.) protein concentrates: functional and rheological properties. Journal of Food Science and Technology, 52(2), 1024-1031. DOI: 10.1007/s13197-013-1110-z

Thakur, M., Nanda, V. 2018. Assessment of physicochemical properties, fatty acid, amino acid and mineral profile of bee pollen from India with a multivariate perspective. Journal of Food \& Nutrition Research, 57(4).

Thakur, M., Nanda, V. 2020. Exploring the physical, functional, thermal, and textural properties of bee pollen from different botanical origins of India. Journal of Food Process Engineering, 43(1), e12935, doi.org/10.1111/jfpe.12935.

Wani, IA., Sogi, DS., Gill, BS. 2013. Physicochemical and functional properties of flours from three black gram (Phaseolus mungo L.) cultivars. International Journal of Food Science and Technology, 48(4), 771e777. DOI: https://doi.org/10.1111/ijfs.12025.

Yang, K., Wu, D., Ye, X., Liu, D., Chen, J., Sun, P. 2013. Characterization of chemical composition of bee pollen in China. Journal of Agricultural and Food Chemistry, 61(3), 708-718, doi.org/10.1021/jf304056b.

Zuluaga, C., Martínez, A., Fernández, J., LópezBaldó, J., Quiles, A., Rodrigo, D. 2016. Effect of high pressure processing on carotenoid and phenolic compounds, antioxidant capacity, and microbial counts of bee-pollen paste and beepollen-based beverage. Innovative Food Science \& Emerging Technologies, 37, 10-17, doi.org/10.1016/j.ifset.2016.07.023. 
Zuluaga-Domínguez, C., Castro-Mercado, L., Cecilia Quicazán, M. 2019. Effect of enzymatic hydrolysis on structural characteristics and bioactive composition of bee-pollen. Journal of
DERLEME / REVIEW

Food Processing and Preservation, 43(7), e13983, doi.org/10.1111/jfpp.13983. 